The Australian Surveyor, March 1991, Vol. 36 No. 1

\title{
LAND INFORMATION MANAGEMENT AT THE WORLD BANK
}

Ian Williamson

Professor of Surveying and Land Information,

The University of Melbourne,

Parkville, Victoria 3052

Ian Williamson spent the latter half of 1989 as a Land Information Consultant in a research position with the World Bank in Washington DC

\section{ABSTRACT}

The surveying, mapping and land information management industry in both the government and private sectors in Australia has increasingly promoted the export of its expertise to developing countries during the 1980s, particularly in the land administration area. This activity has brought the industry in closer contact with organizations such as the World Bank with a view to increasing Australia's share of the international consulting market.

As a consequence of these developments and the extensive expertise in land management within the World Bank, in both the operational and research areas, the author spent six months undertaking research in land information management in developing countries in the World Bank during the latter half of 1989. This paper summarizes his impressions and experiences from this period but in particular highlights the role and importance of surveying, mapping and land information management as perceived by the World Bank.

A major conclusion of the paper is that the surveying profession together with its institutions, systems and technologies is "alive and well" and has a very sound and important future in the developing world.

\section{INTRODUCTION}

Australia has a long history of exporting its expertise in land registration and cadastral surveying and mapping. To some extent this has been due to the success in other jurisdictions of the world renown Torrens System of title registration. Another important factor is the very good reputation of the Australian surveyor. There is evidence of the export of these systems and related services for over a century to many countries in our region and elsewhere.

There appeared to be a reduction of interest in Australia in the export of surveying, mapping and land information management services, especially in support of land administration systems, in the 20th century up to the 1980s. At that time the government sector at both the federal and state levels started to aggressively market their services overseas, often in competition with each other and the private sector. At the same time the Australian International Development Assistance Bureau (AIDAB) increasingly supported surveying, mapping and land information management projects such as in Fiji in the 1970s, Thailand in the early 1980s and Philippines and Papua New Guinea in the late 1980s. To a large degree this was due to a reawakening in the development agencies and individual countries of the importance of land management systems in the economic development of countries, as well as a reduction in the influence of the colonial powers, notably the United Kingdom and France. The developments occurred at the same time as many government and semi-government departments in Australia increased their activities to market their services overseas (and in Australia) partly in response to the necessity of a more aggressive export related economy but also due to the increasing pressures on surveying and mapping 
organizations in government to become more accountable, more cost efficient and overall less of a drain on the public purse.

One result of the increased export related initiatives of the Australian surveying, mapping and land information management industry was an increased interest by the industry in the operations of such organizations as the World Bank, the United Nations Development Program and other development agencies, with a view to attracting a greater share of international consultancies. One initiative which strengthened links between the World Bank and the Australian surveying, mapping and land information management industry was the appointment of an Australasian surveyor, Lynn Holstein, as the first Land Information Specialist to be appointed by the Bank.

As a consequence of the developments in Australia, world wide and in the World Bank and the extensive expertise in the World Bank, in both the operational and research areas, the author spent six months at the Bank in Washington DC undertaking research into land information management in developing countries. The appointment was with the policy, planning and research staff within the Urban Development Division (INURD).

The major objectives of this period at the World Bank were:

- To undertake research into the design, implementation and evaluation of land information systems by drawing on the extensive "real world" experience within the research and operations divisions of the World Bank.

- To extend the author's research and educational horizons by placing the primarily technological discipline of surveying, mapping and land information management in a broad economic and institutional framework as found within the World Bank.

- To extend and broaden the author's understanding of the economic, institutional and technical operation of large cities and in particular identify the role that land information management (LIM) plays in the operation of such cities.

- To obtain an up-to-date insight into the research agenda in land information management in urban areas in developing countries from the point of view of the World Bank.

- To use the World Bank as an example to review the management of research in a business environment.

The objective of this paper is not to give the definitive overview of all land information management activities in the World Bank but to describe the author's experiences and impressions during his six months at the Bank. Due to his interests and his position in the Bank a lot of the work described in this paper is research oriented however due to the nature of the research most of it is closely tied to the Bank's operations. It is hoped that the reader will get a clearer picture of the role and operations of the World Bank in the international development business but at the same time get an appreciation of the role and importance that the surveying, mapping and land information management industry plays in supporting that business. For further information on land information management within the Bank refer to the references and selected bibliography, and particularly the papers by Lynn Holstein (1989a), (1989b), (1989c) and (1990).

\section{THE WORLD BANK AND ITS RESEARCH ACTIVITIES}

The World Bank is a development finance agency. The World Bank Group comprises primarily the International Bank for Reconstruction and Development (IBRD), the International Development Agency (IDA) and the International Finance Corporation (IFC). The IBRD is owned by 151 countries. It has about 6,000 permanent employees. In 1989 the IBRD and the IDA made new commitments totalling US\$21.3 billion. Cumulative commitments total US\$224.2 billion. The 1990 operational budget of the Bank is US\$899.6 million. The research budget for the World Bank in 1989 was US\$20.3. As a comparison Australia's annual international assistance budget (administered by the Australian International Development Assistance Bureau (AIDAB)) is about US\$0.8 billion/year; this compares with the annual 
Bank loan budget to Indonesia for example of about US\$1.2-1.4 billion. For details of Bank operations reference should be made to "The World Bank Annual Report 1989".

The Bank has a primary function of lending money to support development projects in developing countries and for the alleviation of poverty. In the last couple of years the Bank has increasingly placed emphasis on safeguarding and improving the environment, on reducing Third World debt, on the role of women in development and on the reduction of the birthrate in developing countries.

The problems facing developing countries are well documented however the problems are getting worse, with rapid population growth accompanied by increased poverty and environmental degradation, being major issues. As stated by the President of the Bank, Mr Barber Conable, in "The Banks World" (World Bank, 1989:12-13), the world's population took 130 years to grow from one to two billion; but at present rates will take only 10 years to go from the five billion population today to the year 2000's six billion. More than $90 \%$ of this increase will be in the developing world. The United Nations has suggested that the world's population will rise to 8.5 billion by the year 2025 and stabilize at 10 million a century from now. In summary the President of the Bank points out the obvious linkages between the environment, population and sustainable development. He believes we must recognize our collective responsibility to maintain a healthy ecosystem on this planet.

To put this in perspective in mid 1987 the population of OECD countries ( 24 industrialised countries including Australia) was 746 millions and the population of the developing world was about 3,860 millions (excluding Eastern Europe and USSR); total world population about 5,100 millions. These figures are all the more striking when it is considered the GNP per capita (1987 Dollars) is US $\$ 14,670$ for OECD countries and for all developing countries it is US\$700.

The Bank is administered by a Board of Governors, Executive Directors who have the responsibility of overseeing the interests of the donor countries and the President of the Bank. Under the President are four Senior Vice Presidents for: Finance; Operations; Policy, Planning and Research (PPR); and External Affairs and Administration. Under the Senior Vice President for Policy, Planning and Research there are two Vice Presidents for Development Economics and Chief Economist, and Sector Policy and Research. The Vice President for Sector Policy and Research has five departments of Agriculture and Rural Development, Environment, Infrastructure and Urban Development, Industry and Energy, and Population and Human Resources. The Department of Infrastructure and Urban Development has three divisions, namely Transport, Urban Development (INURD) and Water and Sanitation. As mentioned the author worked in INURD during his period at the Bank.

One of the missions of PPR is to strengthen the Bank's capacity and visibility as an institution that creates and shares knowledge. To achieve this, PPR has been given the role of strengthening the Bank's capacity to provide intellectual leadership in the development field and translating the results of research and other analytical work into tangible benefits for the Bank's client countries. The implementation of these objectives requires the Sector Policy and Research

Departments to undertake the following tasks:

- Research

- Formulate Bank policies and sectoral strategies

- Maintain the Bank's technical expertise

- Disseminate the Bank's sector knowledge

Even though the corporate plan for the Bank suggests that the research divisions are a central focus for Bank policy and research, the reality is that the research divisions work closely and in partnership with the operational divisions in developing policies and sectoral strategies. In general, however, they are the clearing house for information on new technologies, worldwide trends and problems and Bank operations (Water and Urban Development Division, 1987). 
The work programs (Infrastructure and Urban Development Department, 1988) of the Sector Policy and Research Departments are approximately two thirds concerned with major policy research, fundamental and applied research, and the preparation of guidelines. Approximately one third of the time is concerned with operational support, and reviewing and monitoring of operations.

The research objectives of the Bank are fourfold:

- To broaden understanding of the development process internally and outside the Bank

- To strengthen the intellectual foundations underpinning the Bank's policy

- To provide important inputs to the Bank's operational work and project design

- To help in developing indigenous research capacity in developing countries (World Bank, 1988)

One of the tasks of the Bank's research administration is to balance the costs of short and long term research. However much of the Bank's research is directed to immediate concerns which have direct relevance to the Bank's operations.

The Bank has a Research and Publications Policy Council which determines research and publications policy. The Bank's research program is administered through the Research Committee which is responsible for translating the Bank's broad research agenda into specific research priorities and for overseeing the Bank's centrally funded (about US\$5 million pa) research program, however this is only a small component of the overall research activity within the Bank. The majority of "research" funding comes from operational projects, sector work, the internal Departments' and Divisions' budgets and bilateral agencies.

While the Bank sets broad research policy there is a reasonable amount of autonomy is setting individual research agendas in the research departments and divisions. Where research programs are externally funded (ie by the United Nations Development Program(UNDP) or individual countries) the Bank permits a broad range of research activities which are not administered through the formal research process.

\section{THE URBAN SECTOR}

Collectively the Bank lends about $50 \%$ of all funds to projects within urban areas, or to projects concerned with or supporting urban systems. Interestingly approximately $60 \%$ of GNP of developing countries comes from urban areas even though these areas contain only about one third of the total population in such countries. Also about $80 \%$ of the growth of GNP of developing countries is in urban areas. Over the past three or four decades urbanization in the Third World has increased from less than 300 million to about 1.3 billion today. In 1988 the urban population in developing countries increased by some 45-50 million as compared to 7-8 million in developed countries. Up to the turn of the century, the cities and towns in the developing world will have to absorb another 600-700 million people or about two thirds of the total world population increase (Infrastructure and Urban Development Department, 1988).

Annually the Bank invests about US\$1.5 billion directly into the urban sector. This amount is matched by other organizations and donor countries. This figure of about US\$3 billion is small considering worldwide about US\$100-150 billion is invested annually in urban housing and infrastructure in developing countries. However the impact of the Bank's lending is far greater than the actual amount which it lends suggests. Through the Bank's urban lending the Bank is able to influence urban policy and the way urban issues are analyzed and solutions formulated and implemented. For more information on the impact of the Bank's urban lending see "Learning by Doing", World Bank (1982), Ljung and Farvacque (1988) and Urban Development Division (1988).

Recent research suggests that despite progress in some areas, the urban environment continues to deteriorate in most developing countries. Evidence of this is the rapid expansion of informal settlements with poor infrastructure facilities and dilapidated houses. Other signs are increasing congestion, air and water pollution, and deteriorating infrastructure. Simply the rapid urbanization has outstripped many, if 
not most, governments' ability to cope with even the most basic of services. Consequently both the Bank and its borrowers have to tackle the serious distortions which exist in the financial, land and housing markets.

As stated in the General Operational Review of the Infrastructure and Urban Development Department titled "Addressing the Urban Challenge" (Ljung and Farvacque, 1988), the Bank's urban agenda is increasingly seeking closer links between traditional urban concerns and the macroeconomic investment and policy framework. The shift has been accompanied by a move away from sporadic interventions to encompass broader issues of greater impact for the national economies and the productivity of cities. As a consequence the major research topics in the Urban Development Division are:

- Municipal finance and management

- Urban infrastructure productivity and willingness to pay for urban services

- Housing markets and housing policy

- Housing finance institutions and policies

- Land management

- Urban environment policy

In the land management area the Division is researching ways to solve the following problems:

- Getting greater involvement of the private sector in developing urban infrastructure and in housing development

- Improving outdated legal and administrative systems for the management of urban systems

- Improving land taxation systems which are more equitable and provide finance for the necessary urban infrastructure

- Improving land administration and in particular land information systems to provide better information for the management of urban systems.

The Urban Development Division consists of about 20 permanent professional staff together with administrative and support staff. In addition the Division has up to 10 research assistants for various lengths of time, but particularly over the summer during university vacations. The professional staff are mainly economists; however the Division also employs engineers, planners and land management specialists.

The Division primarily receives its funding from the Bank's annual budget. This is supplemented by funding from three Bank funded research projects, three UNDP projects and funds from six bilateral donor countries. In addition the Division gives operational support in carefully selected areas. In such cases the Division endeavors to share some of its costs.

In many respects the Division operates in a similar manner to many highly regarded research departments in universities. However where universities have a primary mandate to educate their students, the Division has to serve the corporate requirements of the Bank and in particular the objectives of the donor countries, the operational sectors in the Bank and the Bank's clients (developing countries). Other than these important distinctions the staff of the Division publish academic articles in learned refereed journals, present papers at leading international conferences, symposiums and workshops, and run seminars and workshops for their "clients". Due to the size of the Division, the high calibre of its research staff and its large critical mass, the Division would have to rank as one of the leading research units worldwide, focussing on urban problems in developing countries.

In recognition of the need for research into urban management issues, the Division has established an Urban Management Program to undertake research to strengthen urban management in developing countries (Urban Development Division, 1989a). The program is under the overall coordination of the Urban Development Division in the Bank but is jointly executed with the United Nations Center for Human Settlements (UNCHS-Habitat). The program is supported by the United Nations Development Program (UNDP) and the Governments of the Federal Republic of Germany, the United Kingdom, 
Switzerland and Denmark (though support from other bilateral organizations is forthcoming). A primary objective of the program is to disseminate the lessons of developing countries in city management. The stated aims of the program are to develop policies, programs and instruments which can translate the broad objective of improved urban management into practical measures for more effective interventions in the development of urban areas by municipalities, national governments and external support agencies. The emphasis of the program is on urban interventions as the management of processes rather than a series of discrete projects. There are four main components in the first phase of the program:

- Land Management

- Infrastructure

- Municipal Finance

- Environment

\section{URBAN LAND MANAGEMENT RESEARCH}

As stated, land management research is one of the major research themes being undertaken by the Urban Development Division. While land management has its own research agenda, it impacts on many other research areas in the Division. For example aspects of tenure reform and tenure security are critical in housing research; the role of tenure systems in the provision of collateral for loans is very important to housing finance research; land information systems is essential in infrastructure studies; and land registration and cadastral mapping is an important consideration in municipal finance studies. Also the research work and expertise in the Division in land management and land information systems is relevant and of interest to many other research and operational areas within the Bank. Of interest it has been estimated by the Bank that $40 \%$ of all Bank supported projects suffer from delays in land acquisition and land tenure problems (Ljung and Farvacque, 1988:16).

The interest in land management and land information system issues has been growing steadily in the Bank for nearly a decade to the point today where it is generally recognized that the issues in this area must be understood and addressed for efficient and orderly development to take place in both rural and urban areas in developing countries. As stated by the Water and Urban Development Division in 1987,

"A well functioning land management system - with all its component parts - is essential for orderly urban growth, a dynamic private sector and an efficient housing finance system", and further,

"The issues covered under the convenient title of 'land management' are extremely complex and poorly understood. This is an emerging - but rapidly growing - area of Bank activities where we [the now Urban Development Division] could have a major impact".

The Bank increasingly turned its attention to land management issues in the early 1980's (see Dunkerley, 1983). One of the Bank's activities during this period was to organize a series of workshops on the topic for Bank personnel. Some of the research which was undertaken during the early 1980's concerned the cost of land information systems (Bernstein, 1985), the value of cadastral systems to developing countries (Doebele, 1983) and supporting technologies for land information systems (Morgan, 1985). However the research was fragmented to some extent in the Bank until the mid to late 1980's when the Bank focussed a group of economists, planners and land information specialists on land management issues (including the appointment of an Australian surveyor, Lynn Holstein). The Division is now directing a coordinated research effort at urban land management problems including land information management, land registration, land tenure issues and the related economic aspects (Holstein, 1989a).

Recognizing the problems of poor land management in urban areas in developing countries, the Urban Development Division (Ljung and Farvacque, 1988) believes it is necessary from both an economic and social point of view to have the following systems operational in urban areas: 
- A legal framework that ensures land can be easily bought and sold

- A system of procedures and regulations to ensure the development of land at affordable cost

- Land taxation measures to promote efficiency and equity in land use

- A land registration system which ensures that land ownership can easily be identified and transferred and that property taxes can be assessed and collected.

Research into the above systems forms a basis for a significant amount of the research agenda for land management. However as highlighted in Ljung and Farvacque (1988) changes in land management policies involve a great array of religious, cultural, political, legal and institutional tasks. The complex interaction between these factors is little understood. As a consequence the research agenda and program is evolving and expanding as many of these issues are researched and better understood.

Further justification for the research agenda in land management comes from the experience of the Bank in squatter upgrading projects where lack of secure tenure has a major impact on the welfare of the poor. As stated in the Urban Sector Strategy:

"Usually the lack of secure tenure is not a result of illegal invasion and squatting on public or private land but is due to outdated land tenure laws and inoperative cadastral and land information systems. The lack of land records not only prevents the poor - and many middle income families - from having secure tenure, it also precludes the use of land and houses as collateral for mortgage loans and hinders the assessment and collection of property taxes (which is usually the largest revenue source for local governments)." (Infrastructure and Urban Development Department, 1988:5)

The major research being undertaken in land management within the Urban Development Division is part of the Urban Management Program described previously. The Land Management component of this program is coordinated by Lynn Holstein. The Land Management component has the objectives of making the land market smooth and flowing, facilitating the land supply for urban development (by getting rid of the bottlenecks) and by encouraging an increased role for the private sector in the whole land development process. The program has the following sub-components:

- Land information management

- Land tenure

- Land registration

- Land development policies

- Urban spatial planning

- Standards for land regulation

- Institutional and legal arrangements for land development

- Analysis of land markets

Specific research projects in the land information management and land tenure areas include the preparation of policy and issues papers on land information management, land registration and land tenure. A number of papers will address economic and cost/benefit considerations. An integral part of the research program is a number of case studies of operational systems in developing countries.

\section{RELATED LAND MANAGEMENT RESEARCH}

Land management and land information management issues are also of major concern in many of the Bank's other operations and in particular operations in rural areas as highlighted by the following two quotes from the Bank's World Development Report 1989 (World Bank, 1989c:86-87):

"The legal recognition of property rights - that is, rights of exclusive use and control over 
particular resources - gives owners incentives to use resources efficiently. Without the right to exclude others from their land, farmers do not have an incentive to plow, sow, weed and harvest. Without land tenure, they have no incentive to invest in irrigation or other improvements that would repay the investment over time. Efficiency can be further served by making property rights transferable." (p86)

"In most countries real estate accounts for between half and three quarters of national wealth. If ownership is widely dispersed, tenure is secure, and title transfer is easy, real estate can be good collateral for nearly any type of lending. Unfortunately, these conditions are not always met in developing countries. Land distribution is often skewed, tenure (if any) insecure, and title transfer cumbersome. One key to a smoothly functioning system of land tenure is land registers supported by cadastral surveys. In many developing countries these are still woefully inadequate or missing altogether." (p87)

Much of the research in the World Bank which has supported investment in land titling in rural areas has been done by Gershorn Feder who works in a rural research division (see Feder et al, 1988). His work on showing the economic benefits of land titling was based on the work of the Thailand Land Titling Project.

Other evidence of the depth of understanding of surveying, mapping and LIM issues in the Bank is the work by Francois Falloux (1989) with regard to renewable resource management in Sub-Sahara Africa. This report describes the application of mapping, land and geographic information systems and remote sensing in an institutional and economic framework in rural areas. Another interesting report from the Bank on the application of remote sensing to support planning in urban areas is by Marie-Agnes Bertaud (1989).

The Bank has also done a lot of work on urban property taxation in developing countries (Dillinger, 1988). The results of the Bank's work over many years show that property tax can be an efficient, equitable means of financing municipal services in developing countries, but in most countries it needs reform.

\section{LAND INFORMATION MANAGEMENT IN THAILAND AND GHANA}

The author's period at the World Bank was a valuable opportunity to review some surveying, mapping and land information management projects from the broad economic and institutional viewpoint possible within the Bank. One task was to review the reasons for the success of the Thailand Land Titling Project, a project the author has been involved with for seven years. Another task was to assist with the development of an urban land information management strategy in Ghana. Both these experiences were extremely valuable in placing the role and importance of the surveying, mapping and land information management in the Bank in perspective.

The Thailand Land Titling Project is a successful project in the Bank's view combining technical, institutional, legal and educational components. It is a joint project by the Royal Thai Government, the World Bank and the Australian International Development Assistance Bureau. It is primarily concerned with the issuing of land titles to all freehold parcels in the Kingdom of Thailand, in addition to undertaking land administration improvement, establishing a national valuation system, carrying out urban cadastral mapping for all urban areas in the country and developing a national land information strategy.

The objective of this research was to evaluate the reasons for the success of the Thailand Land Titling Project. The major outcome was that the institutional, economic, social, legal and political environment at the time of project preparation and implementation was conducive to its success. The research highlighted the valuable lessons to be gained by other developing countries studying the Thai experience, however it 
showed that the experiences of Thailand and the reasons for the success of the project are peculiar to the Thai situation and are not easily transferable to other juridictions. Such research and evaluation assists in placing the lessons, achievements and benefits of the project in perspective for others who may wish to translate these experiences to their own countries or jurisdictions.

By drawing on the experiences of the Land Titling Project and other projects with which the author has been involved, an attempt was made to generalize the considerations and necessary environment for success of similar projects. For further details of this review see Williamson (1990).

The experience of developing a LIM improvement strategy for the five major cities in Ghana was very beneficial in being able to place the role of surveying, mapping and LIM in perspective with regard to the operation and improvement of urban areas. It required a broad understanding of the operation of the urban sector including an understanding of the land and housing delivery process, the complexities of customary tenure and the associated land administration system within an overall macro economic strategy.

Previous World Bank reviews had highlighted land issues as being a major limiting factor in the land and housing delivery process, and land administration activities in urban areas in Ghana. Land issues affect the availability of land for housing, the planning and administration of urban areas, the management and upgrading of utilities and infrastructure, the environment and many other activities in the urban sector, as well as constraining the use of land as collateral for housing finance.

During the Bank mission to Ghana it became clear that the Government of Ghana required assistance in two major areas in order to improve the land administration and land delivery systems. Firstly by supporting the development of a systematic land titling process in urban areas to bring all land parcels under a new (1986) land titles legislation which aims to support the giving of clear and easily negotiable title to all parcels. The second priority area is to support the institutional upgrading of the Survey Department such that it can provide basic maps for use with land administration, planning, city administration, land tax and the maintenance and upgrading of utilities and infrastructure. The present lack of these maps is causing severe difficulties in the implementation of many of the supported Bank initiatives in the urban sector.

The strategy of the land administration improvement component in this project is to commence intervention in the land titling and land delivery process in urban areas in Ghana and to undertake essential institution building in the key land administration organizations. The strategy will be achieved in part by supporting a major pilot land titling and adjudication project in the two major cities, and by providing critical institutional support to training and education in the surveying, mapping and land administration areas. In addition the component will undertake several studies in cooperation with the United Nations Development Program initiatives in the urban sector in Ghana. The result of these activities will be that both the Government of Ghana and the Bank can tightly focus and target their initiatives to support a planned major component addressing land administration and mapping improvement in a future Bank supported urban project in several years.

\section{CONCLUSION}

The greatest benefit from the period in the World Bank was the opportunity of examining surveying, mapping and land information management from a broad economic and institutional perspective. Surveying, mapping and land information management are not ends in themselves, they contribute to the operation of a broad range of activities in both the urban and rural sectors in developing countries. One of the primary activities is the contribution to the efficient management and administration of land which in the urban context is closely tied to land and housing delivery, the housing finance system, town planning, utility and infrastructure management, land taxation, land ownership, land transfer and land development. In the rural context it is tied for example to increased agricultural productivity through improved security of tenure, environmental management and land taxation. In general the economic return or benefit of these activities are considered by the Bank thereby permitting the overall benefit of improved land 
management to be assessed in broad macro economic terms.

By examining the operation of a country globally it is possible to view the role and importance of surveying, mapping and land information management with regard to all the other activities which support the running of a country. For example the paper has attempted to show linkages firstly between surveying, mapping and LIM, and land management, secondly between land management and the urban sector, and thirdly between the operation of the urban sector and the overall operation of a country. Surveying and mapping activities are clearly central to the operation of developing countries. It is heartening to see an apparent growing awareness of the importance of these activities in organizations such as the World Bank.

During the period at the Bank it was possible to review the use and application of technology in land management. In summary, technology is certainly impacting on the surveying, mapping and land information management activities in developing countries but to varying degrees. Computerization, electronic distance measurement, the Global Positioning System (GPS), digital photogrammetry and remote sensing are all having an impact, but generally only where the technology is affordable, appropriate and sustainable.

Another valuable lesson from the Bank experience is the emphasis that is placed on project preparation and project management by the World Bank. It would not be unreasonable for the Bank to spend US\$1 million on project preparation for a US\$20 million project. Since it is a "bank" it takes the necessary and important approach at looking at the economic rate of return of its investments where possible. This is an area which is often little understood in many disciplines, and in particular in disciplines such as planning, urban management, surveying and mapping and land information management.

Another important aspect of the Bank's work is the manner it supports its operational activities with an extensive research capability which contributes to new policies, improved operations and the supply of specialist expertise when required. It is suggested that this model of supporting operational activities with good research backup will be an increasing requirement for success in the future for the Australian surveying, mapping and LIM industry in both the government and private sectors.

The author's period at the World Bank was also a good opportunity to reflect on the benefits to be gained from exporting Australia's surveying, mapping and land information management expertise. In general Australia does relatively poorly in attracting its "share" of contracts from organizations like the World Bank. The industry should be looking closely at the benefits to be gained from exporting its services. In many cases the ad hoc approach to marketing of its services is inefficient and expensive. At the same time the economic benefits to Australia from government involvement in some projects is questionable. On the other hand if Australia wishes to be a major force internationally in consulting in surveying, mapping and land information management the industry must be prepared to make a significant up front investment in order to position itself in the market. Staff training and the gaining of international experience however can only benefit the industry in Australia. This is one of the very real benefits from international consulting in our industry.

In summary the overall impression from this period at the World Bank is that the surveying profession, together with its related institutions, systems and technologies, is "alive and well" and has a very sound and important role in the developing world.

\section{ACKNOWLEDGEMENTS}

The author gratefully acknowledges the support of The University of Melbourne, the World Bank and the Australian-American Educational Foundation (the Fulbright Program) in supporting this research.

The views and interpretations expressed in this paper are those of the author and should not be attributed to the World Bank, to its affiliated organizations, or to any individual acting on their behalf. 


\section{REFERENCES AND SELECTED BIBLIOGRAPHY}

Bernstein, J. (1983). The costs of land information systems Water Supply and Urban Development Department, World Bank.

Bertaud, M. (1989). The use of satellite images for urban planning: A case study from Karachi, Pakistan. Technical Note, INU Report 42. Infrastructure and Urban Development Department, World Bank.

Dillinger, W. (1988). Urban property taxation in developing countries. Working Paper, World Development Report. Infrastructure and Urban Development Department, World Bank.

Doebele, W. (1983). Why cadastral systems are important for less developed countries. Water Supply and Urban Development Department, World Bank.

Dunkerley, H. (ed.) (1983). Urban Land Policy: Issues and Opportunities. Oxford University Press.

Falloux, F. (1989). Land information and remote sensing for renewable resource management in SubSahara Africa: A demand driven approach. World Bank Technical Paper No 108, World Bank.

Feder, G., T.Onchan, Y.Chalamwong and C.Hongladarom, (1988). Land Policies and Farm Productivity in Thailand. A World Bank Research Publication. The John Hopkins University Press.

Holstein, L.C. (1989a). Land Management Information for Urban Development: Needs, Issues and Options - Improving the supply of land information for urban development. Discussion paper (Draft), Infrastructure and Urban Development Department, World Bank.

Holstein, L.C. (1989b). Urban land management: objectives, issues, framework, some Bank experience. Proceedings of the Urban Land Seminar, Annapolis, December. Urban Development Division, World Bank.

Holstein, L.C. (1989c). Land information management: demand, issues and options. Proceedings of the Urban Land Seminar, Annapolis, December. Urban Development Division, World Bank.

Holstein, L.C. (1990). Land information management: Issues and opportunities in developing countries. Proceedings of the United Nations Inter-regional Seminar on Land Information Management and the Developing World. Adelaide, Australia, February.

Infrastructure and Urban Development Department, (1988). Sector Strategy - Urban. World Bank, November.

Ljung, P. and C. Farvacque, (1988). Addressing the Urban Challenge - A Review of the World Bank FY87 Water Supply and Urban Development Operations. Report INU 13. Infrastructure and Urban Development Department, World Bank, March.

Morgan, G. (1985). Land information systems: Design considerations for the organization of supporting technologies. Cartography Division, World Bank.

Urban Development Division, (1988). The Emerging Role of Housing Finance - FY88 Annual Review of Urban Development Operations. Report INU 33. World Bank, November.

Urban Development Division, (1989a). Urban Management Program - Overview of Program Activities. World Bank, February.

Urban Development Division, (1989b). FY89 Sector Review; Urban Development Operations - Reaching the poor through urban operations. World Bank, November. 
Water and Urban Development Division, (1987). Internal policy and strategy paper. World Bank.

Williamson, I.P. (1990). Considerations in assessing the potential success of a cadastral project in a developing country - a case study of the Thailand Land Titling Project. Submitted to The Australian Surveyor for publication.

World Bank. (1983). Learning by Doing - World Bank Lending for Urban Development, 1972-1982.

World Bank, (1988). Annual Report 1988.

World Bank, (1989a). Annual Report 1989.

World Bank, (1989b). The Banks World. Volume 8, Number 7, July.

World Bank, (1989c). World Development Report 1989. Oxford University Press, June.

World Bank, (1989d). Debate over land registration persists. The Urban Edge, Vol 13, No 7, AugustSeptember.

Yahya, S. (1982). House Registration Handbook: A model for registering houses and plots in unplanned settlements. Technical Paper No 4. Urban Development Department, World Bank. 


\section{University Library}

\section{- M M I E E R VA A gateway to Melbourne's research publications}

Minerva Access is the Institutional Repository of The University of Melbourne

Author/s:

Williamson, lan P.

Title:

Land information management at the World Bank

Date:

1991-03

Citation:

Williamson, I. P. (1991). Land information management at the World Bank. The Australian Surveyor, 36(1).

Publication Status:

Published

Persistent Link:

http://hdl.handle.net/11343/34023 